\title{
What Matters When Purchasing Fresh Agri-Food for Taiwanese Consumers? A Best-Worst Scaling Approach
}

\author{
Ching-Hua Yeh \\ Institute for Food and Resource Economics, University of Bonn, Bonn, Germany \\ Email: chinghua.yeh@ilr.uni-bonn.de
}

How to cite this paper: Yeh, C.-H. (2020) What Matters When Purchasing Fresh Agri-Food for Taiwanese Consumers? A Best-Worst Scaling Approach. Open Journal of Business and Management, 8, 135-155. https://doi.org/10.4236/ojbm.2020.81009

Received: October 28, 2019

Accepted: December 14, 2019

Published: December 17, 2019

Copyright $\odot 2020$ by author(s) and Scientific Research Publishing Inc. This work is licensed under the Creative Commons Attribution International License (CC BY 4.0).

http://creativecommons.org/licenses/by/4.0/

\begin{abstract}
Consumers' food purchase decision is multifaceted and complex, which is not only influenced by product and process characteristics, but also by the present decision-making circumstances. This study investigates this complexity of consumers' food choice influenced by product and process characteristics, as well as by the decision-making circumstances (i.e. tactile sensory aspects of the product and shopping location), using best-worst scaling (BWS) methodology. BWS allows measuring the importance of different food buying criteria, thereby eliciting consumers' preferences. A total of 795 food consumers participated in a street-intercept interview performed in three cities of Taiwan. Results indicate that among the nine food purchase criteria (e.g. country-of-origin $(\mathrm{CoO})$ labelling, production methods, chemical residue testing (CRT) information, price, shopping location, visual appearance, sense of touch, package size, and a recommendation given by a significant one), CRT information is the most important criteria in consumers' purchase decision, followed by $\mathrm{CoO}$, production methods and hedonic characteristics. Three segments of consumers can be distinguished: the health-conscious purchasers $(50.20 \%)$, the hedonic buyers $(31.90 \%)$, and the origin-driven shoppers (17.90\%).
\end{abstract}

\section{Keywords}

Best-Worst Scaling, Mixed Logit Model, Latent Class Analysis, Agri-Food

\section{Introduction}

The food market is an extremely complicated and widespread system. There is plenty to find out about how and why consumers choose food. For instance, it 
could be the motive that a bar of chocolate, a carton of milk, or a piece of sweet pepper is produced in your local area or around the world; they could be produced underlying a conventional production method or an organic production method; they could be grown with numerous concentrated synthetic pesticides or just a few amounts of chemical inputs; they could be sold with a price premium or a discount price. Regarding the aforementioned attributes, without food labelling information consumers will neither be able to distinguish many food products on the shelves, nor be able to determine where and how the food is produced. Therefore, labels of product and process characteristics provide consumers with information for making adequate buying decision [1] [2].

The process of consumers purchasing food is multifaceted and complex. Numerous previous studies analysed consumers' food consumption, focusing on the impact of extrinsic observable cues such as (governmental regulated) food labelling (i.e. origin labelling, organic labelling, price) [3]-[9], many of which targeted to assess the impacts of food labels for consumers with regard to their food purchase decision. Particularly, along with escalating living standards and rising anxieties with respect to consumers' demands for information on food safety and quality, the importance of food origin and production methods has increased extremely [10]. Repeatedly the country of origin ( $\mathrm{CoO})$ labels have been discovered to be perceived as more important compared with labels for production methods [3] [8] [9] [11]. However, the increase in food business competitiveness often triggers additional difficulty for consumers who have to process plentiful information on food. Consumers' food purchase decision is rarely formed exclusively by visible product or process attributes. Rather, it is determined by a combination of different factors [12] [13]. Those include the visual and tactile sensory aspects of the product [14] [15] [16] during consumers' food shopping activity, the specific environment the purchase takes place (e.g. shopping location) [17] [18] as well as recommendations given by significant others (e.g. partners, family or friends) [19] [20]. Although many of those criteria are difficult to measure, they nevertheless might strongly impact consumers' food buying strategy.

The most ideal techniques to advance the understanding of which characteristics and combinations that lead consumers to purchase a particular food product was to utilize either discrete choice experiments (DCE) [9] [21] [22] or to explore choice-based experiments bounded to real consumer food purchases [23] [24] [25]. DCEs are an effective method for presenting various combinations of product's visible characteristics, named product concepts or alternatives, in which the participant is forced to trade off among different alternatives. Although the DCE method allows novel attributes and levels combinations to be included and examined for preference with respect to a specific food product, one of the DCE's drawbacks is its complex experimental design and the difficult interpretation of the analysed results. Especially, in the DCE design participants' individual purchase environment and personal decision-making condition (which is typically set identical in terms of e.g. the perceived sensory properties 
such as the ripeness and the outer appearing of the studying object, as well as the individual shopping environment) are hard to be considered exclusively. Therefore, many researchers still tend to utilize the traditional rating scale (e.g. Likert scale 1 to 5 points) for consumer data recruitment. Predominantly it seems to smooth the data analysis and its interpretation of the analysed outputs. While the rating questions are easy for participants to respond; they may ineffectually discriminate between attributes/items and may face the difficulties to trade-off between attributes/items [26] [27] [28].

Given the complexity of consumers' (food) decision making behaviour and the potential scaling problem this paper uses the best-worst scaling (BWS) methodology [29]. BWS is a manifold choice extension of a paired comparison case. In BWS question, participants are requested to select the most preferred attribute/item (named "best") and the least preferred attributes/item (named "worst") in a BWS choice set. Cohen and Markowitz [30] state that there is only one mode for selecting the most and least preferred item in the BWS task. Participants are forced to discriminate among items and cannot dependably use the middle or end points as what they do for Likert scaling task. In addition, one advantageous point of employing BWS approach is that a complete ranking of the attributes analysed can be sufficiently obtained via the evaluation of how attributes relative to each other in the BWS data. Accordingly, the BWS results are more sensible and discriminating than rating scales [31]. As to the present study, the feasible details in designing and applying BWS experiment using food purchase related criteria will be expressed in the latter section of this paper.

Regarding the complication of the consumer decision making process, little is known about which food purchase criteria are actually of specific relevance for consumers, whether there are differences between consumer segments and if so, what are the profiles of those segments, Thus, this paper seeks to contribute to the broader study of consumers' food consumption behaviour. The purpose of this study is to understand Taiwanese consumers' preference for food purchase interrelated characteristics, not only considering the inward product-specific aspects but also the outer product-specific phases such as the store locations, personal sensory viewpoints and the impact of social norm acquisition, that have different extents of attributes appreciated. Hence, the study contributes to the food consumption literature twofold. Besides extrinsic food attributes it also considers other factors (e.g. shopping location, the aspect of social norm acquisition) potentially relevant in consumers' decision-making process. The random parameter logit model with hierarchical Bayesian estimation and latent class analysis are used to identify the preference heterogeneity in food preferences. Preference heterogeneity is investigated and characteristics of different consumer clusters are unfolded.

The remainder of the paper is structured as follows: Section 2 provides an overview of the conceptual framework and BWS choice experimental design, as well as the analytic method that is implemented; Section 3 reports the empirical specifications used in the model and the analysed results. Finally, a summary 
and concluding remark are presented in the final section.

\section{Method}

There is considerable interest in the method of BWS of preference elicitation in many research fields, especially in the food marketing sector [32] [33] [34] [35]. BWS is an attributed-based methodology that asks interviewed participants to choose the "best" and "worst" items across a series of repeated BWS choice tasks. BWS was firstly introduced by Adam Finn and Jordan Louviere [29]. It is based on the random utility framework [36] [37] and used to measure the relative importance value that individuals attach to different items. The presents study uses the classic case [38] of the BWS method to investigate the preferences of Taiwanese consumers towards unpacked fresh agri-food. In order to construct the research as concrete as possible fresh unpacked sweet pepper was taken as exemplary object. It is a common seen household food ingredient in Taiwan and it is available in either conventional or organic quality, as well as in different production countries that were exemplified in this study. Hence, imaging a situation of sweet pepper purchase is therefore an easy task for study participants.

\subsection{BWS Experimental Design and Instruments}

An intensive literature review and a focus group video conference was conducted to ensure that the selected food-related items covered characteristics of importance to consumers and thus is relevant to influence consumers' decision making on food purchase. The items were pre-tested in the BWS experimental setting. The final nine selected items (see Table 1) were expressed as follows: 1) "country of origin $(\mathrm{CoO})$ " was selected as an important criterion, because it has a greater impact on product evaluation particularly for low-involvement product [39] [40], such as food products; 2) "production method" is considered as an important BWS item by reason of the increasing organic food consumption among Taiwanese consumers due to the organic agriculture and

Table 1. Nine items used in BWS experimental design.

BWS Items

1) Country of origin

2) Production method

3) Chemical residue testing information

4) Price

5) Shopping location

6) Visual appearance

7) Sense of touch

8) Package size

9) Someone who is important to me recommend it 
the organic food market have developed rapidly in Taiwan [41] [42] ; 3) "chemical residue testing ( $C R T$ ) information" is included since the study on food safety topics shows that chemical and pesticide residues are important issues for consumers [43]. Particularly, after several food fraud incidences, information on CRT of food products are in some cases displayed by Taiwanese food retailers [44] [45] [46]; 4) "price" is known to be the driving force for consumer's purchase decision [47] [48]; 5) "shopping location" is considered owing to the finding reported by [49] and [50] that the choice of store location and the distance of store from home is a decision that a food shopper is fairly involved in their food purchase decision making process; 6) "visual appearance" and the 7) "sense of touch" are concerned in the BWS design, because visual and tactile multisensory evaluation influence overall consumer attitude towards products as well as the purchase intentions [51] [52] [53]; 8) "package size" is considered as an influential criterion in the BWS design. Scott et al. [54], Aerni et al. [55] and Wansink [56] found that the package size might affect the consumption behaviour; 9) "recommendations by family and close friends" are considered due to the social-influence effect that has been determined as a factor affecting consumption behaviour [57] [58]. Moreover, in the BWS choice design the exemplary descriptions of each item were used to ensure that the specification of each item referred to the same vision across participants.

A frequency balanced choice design ${ }^{1}$ was generated using MaxDiff Designer v.6 [59] to maximize the BWS design efficiency [60] [61] in the BWS choice experiment. By employing such a design, a nine-item BWS experiment with 120 choice tasks was generated with 30 blocking versions, where each version of the BWS questionnaire had four BWS choice sets consisting of five items in a choice task (see Figure 1). The participants were requested to look at a set of items

\begin{tabular}{|c|c|c|}
\hline \multicolumn{3}{|c|}{$\begin{array}{l}\text { Please considering only these } 5 \text { shopping criteria, and indicate which one } \\
\text { is the most important and which one is the least important to you when } \\
\text { purchasing sweet peppers? } \\
\text { Please tick the most important item at the right side, and tick the least important } \\
\text { item at the left side. }\end{array}$} \\
\hline $\begin{array}{c}\text { Least } \\
\text { Important }\end{array}$ & Items & $\begin{array}{c}\text { Most } \\
\text { Important }\end{array}$ \\
\hline 0 & Country-of-origin & 0 \\
\hline c & Product methods & 0 \\
\hline 0 & Chemical residue testing results & 0 \\
\hline$c$ & Price & $c$ \\
\hline 0 & Shopping location & 0 \\
\hline
\end{tabular}

Figure 1. Example of BWS choice task (translated English version).

\footnotetext{
${ }^{1} \mathrm{~A}$ frequency balanced choice design creates an experimental design that features item frequency balance. A balanced design is one in which the one-way frequencies are almost equivalent (the frequencies each item appears across the entire design) and two-way frequencies are also nearly equivalent (the frequencies each pair of items appear within the same choice task across the entire experimental design). The orthogonality is reached when one-way and two-way frequencies are balanced.
} 
making trade-offs among choice tasks, which item impacts their choice the most and least, and choose from each choice scenario the most important and the least important item in a BWS choice task. One advantage of BWS is its easiness for participants to respond, particularly when large numbers of attributes or items need to be compared [62] [63] [64].

Data were collected via standardized street-intercept computer-assisted interviews with consumers in the retail outlets in three biggest cities of Taiwan (New Taipei city, Kaohsiung city and Taichung city) in 2014. The questionnaire consisted of two parts. In the first part the BWS experiment was presented, while the second part included questions on information on food consumption habits and socio demographics.

\subsection{Econometric Analysis}

As regards the BWS analysis, a descriptive counting analysis was firstly conducted to have the initial picture of the BWS data. Subsequently, a hierarchical Bayesian mixed multinomial logit (MXL) model was applied to quantify the relative importance of the nine items for consumers' decision-making processes at the individual-level. The MXL model takes into account the heterogeneity in consumer preference and overcomes the major limitation of the standard multinomial logit model by allowing random variation and unrestricted substitution patterns for estimating the random coefficients logit model [65]. Following Louviere et al. [38], the econometrics formula with respect to the choice probability of the individual $n$ of choosing item $j$ as the best and $j^{\prime}$ as the worst can be specified as:

$$
P=\frac{\exp \left(\beta_{n} X_{n j}^{\prime}-\beta_{n} X_{n j^{\prime}}^{\prime}\right)}{\sum_{\substack{j, j^{\prime} \in J \\ j \neq j^{\prime}}} \exp \left(\beta_{n} X_{n j}^{\prime}-\beta_{n} X_{n j^{\prime}}^{\prime}\right)}
$$

where $\beta_{n}$ is the individual-specific preference parameter vector obtained by individual $n, X_{n j}^{\prime}$ is the vector of observable explanatory variables including the chosen alternative $j$ (the most important item is coded as 1 , where the least important item is coded as -1 , and non-chosen item is coded as 0 ). Assuming that an individual $n$ choose item $j$ and $j^{\prime}$ as the most important and the least important item in a choice scenario, respectively, out of a choice set of $J$ items.

Additionally, we further examined the BWS data via latent class analysis (LCA) [66]. LCA allows investigating if there are distinct consumer segments that can be clustered based on their preference characteristics; therefore, consumers' preference heterogeneity inherent in the decision-making procedure can be uncovered. The number of latent classes is determined by the researcher based on the statistical measures of fit such as Percent Certainty (Pct. Cert.) [67] [68], Akaike Information Criterion (AIC) [69], Bayesian Information Criterion (BIC) [70], and chi-square scores. Finally, we utilized the Kruskal-Wallis non-parametric test [71] to examine whether different consumer segment significantly differ with respect to the demographic information. 


\section{Results and Discussion}

The consumer survey was conducted with a sample of 1309 Taiwanese consumers in 2014. In total, 795 respondents $(60.7 \%)$ were valid for the upcoming BWS modelling analysis. Participants were screened out if they were not (partly) responsible for their household food purchase as well as if they did not consume sweet pepper. Table 2 presents the summary of the socio demographic statistics of the interview sample. The results show that $45 \%$ of respondents were fully responsible and $55 \%$ of respondents were partly responsible for their household food shopping. $28.8 \%$ of survey participants were male and $71.2 \%$ female, reflecting that due to the cultural reason female consumers are still to a large extent responsible for the food preparation and purchasing in their household in Taiwan. The majority of the participants were in the age range of 30 to 49 years old (63.4\%), married (61.5\%), had a university degree (50.7\%) and a monthly household net income over NT60,0012 $(44.9 \%)$. In general, we can say that the sample is biased towards younger, better educated and wealthier Taiwanese retail shoppers.

Table 3 presents the proportion of the best count and worst count of BWS data via the descriptive counting analysis. The "Best count proportion" and the "Worst count proportion" refer to the probability that participants choose an item as best or worst when it was available within a BWS choice task. It is calculated by the presence of times each chosen item was divided by the presence of times it was shown to participants (available for the BWS choice). The descriptive BWS results are aimed to provide a brief idea of consumers' preference. As to Taiwanese consumers' food shopping criteria, we observed that the highest best count proportion is the chemical residue testing information, followed by the country-of-origin and production methods in rank. The package size, a recommendation of a significant one and the shopping location are ranked the utmost worst count proportion.

Table 4 summarizes the results of the MXL model. The result of MXL model reveals that the most important criteria for consumers in their purchase of sweet pepper is information provided on chemical residue testing with the rescaled important score of 24.69; 95\% C.I. [24.16, 25.23], followed by the CoO labeling (17.70; 95\% C.I. [17.06, 18.34]), production methods (16.60; 95\% C.I. [15.82, $17.38])$, and the tactile sense of food (15.17, 95\% C.I. [14.58, 15.75]). Conversely, the attributes shopping location $(1.83 ; 95 \%$ C.I. $[1.51,2.16])$, recommendation of others $(1.44 ; 95 \%$ C.I. $[1.18,1.70])$ and package size of the product $(0.92 ; 95 \%$ C.I. $[0.74,1.11])$ are according to our finding of least relevance. We also discovered that the results of MXL model and descriptive counting analysis showed a high level of consistency in the importance of food shopping criteria. The MXL empirical results are in line with previous findings [72] [73] [74] reveal that CoO labelling has a greater importance for consumers' preference formation than price. Betts et al. [75] investigated Chinese consumers' attitudes towards ${ }^{2}$ In July 2014, 1 US Dollar $=29.98$ New Taiwanese (NT) Dollars. 
Table 2. Demographic statistics of the respondents.

\begin{tabular}{|c|c|c|}
\hline \multirow{2}{*}{$N$} & \multicolumn{2}{|c|}{795} \\
\hline & Freq. & $\%$ \\
\hline \multicolumn{3}{|l|}{ Shopping responsibility } \\
\hline Full & 358 & 45.0 \\
\hline Partly & 437 & 55.0 \\
\hline \multicolumn{3}{|l|}{ Gender } \\
\hline Male & 229 & 28.8 \\
\hline Female & 566 & 71.2 \\
\hline \multicolumn{3}{|l|}{ Age } \\
\hline Up to 29 & 139 & 17.5 \\
\hline $30-49$ & 504 & 63.4 \\
\hline 50 and over & 147 & 18.5 \\
\hline n.a. & 5 & 0.60 \\
\hline \multicolumn{3}{|l|}{ Living location } \\
\hline North & 197 & 24.8 \\
\hline Middle & 315 & 39.6 \\
\hline South & 270 & 34.0 \\
\hline Other (e.g. East or Islands) & 13 & 1.60 \\
\hline \multicolumn{3}{|l|}{ Living Area } \\
\hline Bid city & 372 & 46.8 \\
\hline Middle size city & 227 & 28.6 \\
\hline Rural area or countryside & 196 & 24.7 \\
\hline \multicolumn{3}{|l|}{ Marital status } \\
\hline Single & 256 & 32.2 \\
\hline Married & 489 & 61.5 \\
\hline Other (e.g. divorced/ widowed) & 37 & 4.70 \\
\hline n.a. & 13 & 1.60 \\
\hline \multicolumn{3}{|l|}{ Education } \\
\hline Senior high school (12 years) & 175 & 22.0 \\
\hline College & 180 & 22.6 \\
\hline University and over & 403 & 50.7 \\
\hline n.a. & 37 & 4.70 \\
\hline \multicolumn{3}{|l|}{ Monthly net income in a household } \\
\hline Up to NT 60,000 & 292 & 36.7 \\
\hline NT 60,001 and over & 357 & 44.9 \\
\hline n.a. & 146 & 18.4 \\
\hline
\end{tabular}


Table 3. Descriptive counting analysis of BWS data.

\begin{tabular}{lcc}
\hline \multicolumn{1}{c}{ BWS Items } & $\begin{array}{c}\text { Best count } \\
\text { proportion }\end{array}$ & $\begin{array}{c}\text { Worst count } \\
\text { proportion }\end{array}$ \\
\hline 1) Country of origin & 0.30 & 0.06 \\
2) Production method & 0.29 & 0.09 \\
3) Chemical residue testing information & 0.54 & 0.01 \\
4) Price & 0.20 & 0.11 \\
5) Shopping location & 0.04 & 0.45 \\
6) Visual appearance & 0.16 & 0.09 \\
7) Sense of touch & 0.23 & 0.05 \\
8) Package size & 0.02 & 0.47 \\
9) Someone who is important to me recommend it & 0.03 & 0.46 \\
\hline
\end{tabular}

Table 4. Mixed multinomial logit model.

\begin{tabular}{|c|c|c|c|}
\hline Number of aggregate participants & \multicolumn{3}{|c|}{795} \\
\hline Models & \multicolumn{3}{|c|}{ Mixed multinomial logit model } \\
\hline Total "Best" Choices & \multicolumn{3}{|c|}{3180} \\
\hline Total "Worst" Choices & \multicolumn{3}{|c|}{3180} \\
\hline $\mathrm{RLH}^{3}$ model fit statistics & \multicolumn{3}{|c|}{0.61} \\
\hline$(0 \text { to } 100 \text { rescaled importance scores })^{4}$ & Rank & $\begin{array}{l}\text { Importance } \\
\text { score }\end{array}$ & $\begin{array}{c}\text { 95\% C.I. } \\
\text { [Lower, Upper] }\end{array}$ \\
\hline 1) Country of origin & 2 & 17.70 & {$[17.06,18.34]$} \\
\hline 2) Production method & 3 & 16.60 & {$[15.82,17.38]$} \\
\hline 3) Chemical residue testing information & 1 & 24.69 & {$[24.16,25.23]$} \\
\hline 4) Price & 5 & 11.29 & {$[10.62,11.97]$} \\
\hline 5) Shopping location & 7 & 1.83 & {$[1.51,2.16]$} \\
\hline 6) Visual appearance & 6 & 10.35 & {$[9.76,10.95]$} \\
\hline 7) Sense of touch & 4 & 15.17 & {$[14.58,15.75]$} \\
\hline 8) Package size & 9 & 0.92 & {$[0.74,1.11]$} \\
\hline 9) Someone who is important to me recommend it & 8 & 1.44 & {$[1.18,1.70]$} \\
\hline
\end{tabular}

sustainability attributes of New Zealand kiwifruit and detected that at point of sale Chinese consumers favoured products free of chemical residues and of environmental-friendly production. In addition, Yeh and Hartmann [76] show that CRT information is perceived as more important than organic certification labelling in the discrete choice experimental setting; however, in their result of DCE it was perceived contradicting that the CoO labelling was the most impor-

${ }^{3} \mathrm{RLH}$ is the abbreviation for root likelihood and the model fit measure. RLH is a geometric mean of the standardized predicted likelihood values associated with the alternatives actually selected by participants. The higher the RLH value, the better the model fit.

${ }^{4}$ Concerning the interpretability of the results, the results are rescaled ranging from 0 to $100 \mathrm{scaling}$. 
tant attribute. This might be explained by the practice of different scope of food purchase interrelated criteria and the study experimental design conducted in the experiment.

Table 6 presents the LCA findings of the BWS data. LCA is a technique of segmenting consumers into homogenous groups based on their preference structure [66]. The first step taken to formally identify the number of latent classes was based on the information criteria via examining how our LCA model performs as we increase the number of segments. Our results for segment selection are shown in Table 5. Information criteria statistics are calculated by evaluating the degree of improvement in explanatory power adjusted by the degrees of freedom [77] [78] [79]. Table 5 presents the four major (common seen) criteria of Percent Certainty (Pct. Cert.) [67] [68], Akaike Information Criterion (AIC) [69], Bayesian Information Criterion (BIC) [70], and chi-square scores used to determine the best latent class model fit. As there are many information criteria that can be calculated, and all provide few specific limitations corresponding to log likelihood statistics. According to the information criteria and the reference of model selection suggested by Nylund et al. [80], the LCA model with improvement across the greatest number of criteria [77] was identified and a three-class solution model specification was selected. In Table 5 the best solution for each criterion is shaded.

The LCA results revealed three distinct classes of food shoppers in Taiwan. Each consumer group consists of different preference structure (see Table 6 and Figure 2). Results of LCA revealed that consumers have heterogeneous preferences for different food related attributes when purchasing fresh sweet pepper.

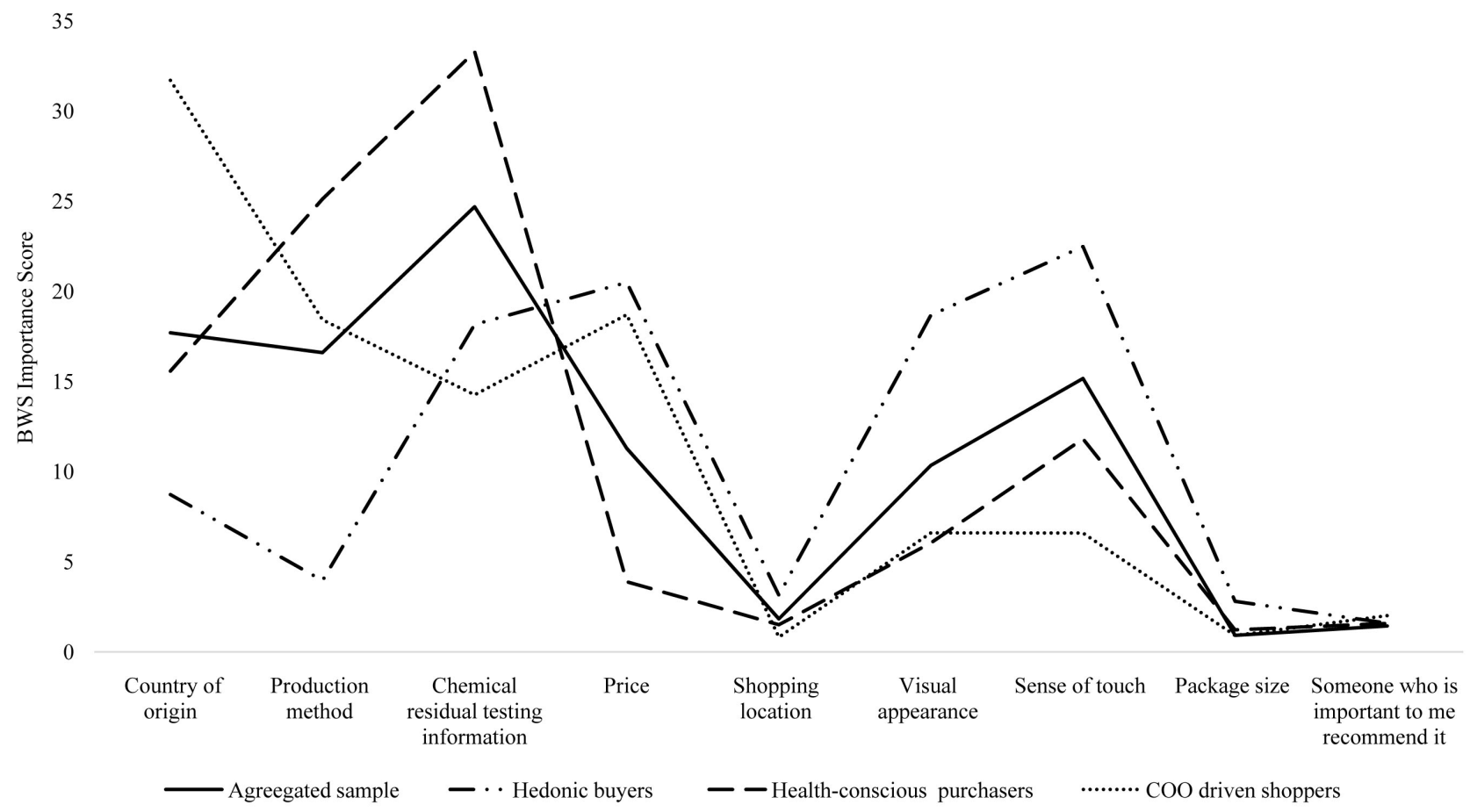

Figure 2. Rescaled importance scores for the aggregate sample (MXL results) and the three latent class sample (LCA results). 
Table 5. Summary of best replications for latent class analysis (the best fit on each criterion is shaded).

\begin{tabular}{cccccc}
\hline Groups & Log-likelihood & Pct. Cert. & AIC & BIC & Chi-Square \\
\hline 2 & $-7,129.87$ & 30.35 & $14,293.74$ & $14,408.62$ & $6,212.31$ \\
3 & $-6,967.91$ & 31.93 & $13,987.82$ & $14,163.52$ & $6,536.23$ \\
4 & $-6,861.33$ & 32.97 & $13,792.65$ & $14,029.17$ & $6,749.40$ \\
5 & $-6,769.25$ & 33.87 & $13,626.51$ & $13,923.85$ & $6,933.54$ \\
\hline
\end{tabular}

Table 6. Latent class analysis.

\begin{tabular}{|c|c|c|c|}
\hline Number of aggregate participants & & 795 & \\
\hline Models & & Latent class model & \\
\hline Log-likelihood for null model & & $-10,236.03$ & \\
\hline Log-likelihood for restricted model & & -6967.91 & \\
\hline Chi-Square & & 6536.23 & \\
\hline BIC & & 14163.52 & \\
\hline AIC & & 13987.82 & \\
\hline Segmentation description & $\begin{array}{l}\text { Hedonic } \\
\text { buyers }\end{array}$ & $\begin{array}{l}\text { Health-conscious } \\
\text { purchasers }\end{array}$ & $\begin{array}{l}\text { COO driven } \\
\text { shoppers }\end{array}$ \\
\hline Segment Sizes & $31.90 \%$ & $50.20 \%$ & $17.90 \%$ \\
\hline$(0 \text { to } 100 \text { rescaled importance scores })^{5}$ & Imprt. score & Imprt. score & Imprt. score \\
\hline 1) Country of origin & 8.72 & 15.57 & 31.7 \\
\hline 2) Production method & 3.95 & 25.12 & 18.42 \\
\hline 3) Chemical residue testing information & 18.16 & 33.28 & 14.26 \\
\hline 4) Price & 20.49 & 3.89 & 18.7 \\
\hline 5) Shopping location & 3.14 & 1.5 & 0.82 \\
\hline 6) Visual appearance & 18.67 & 6.04 & 6.6 \\
\hline 7) Sense of touch & 22.48 & 11.81 & 6.59 \\
\hline 8) Package size & 2.8 & 1.22 & 0.91 \\
\hline $\begin{array}{l}\text { 9) Someone who is important } \\
\text { to me recommend it }\end{array}$ & 1.59 & 1.58 & 2.01 \\
\hline
\end{tabular}

The biggest consumer group consists of health-conscious purchasers $50.20 \%$ of the sample); this outcome is in line with the finding reported by [81], [82], and [83]. This cluster represents consumers that reveal a strong focus on information regarding chemical residue testing and production methods but care less for price (compared to the other groups). Mauracher et al. [81] reported that consumers are interested in buying health-oriented organically-bred Mediterranean Sea bass at a higher premium price. Realini et al. [82] found that the "health conscious consumers" assigned highest importance to the health-related factor, ${ }^{5}$ Concerning the interpretability of the results, author rescaled the results ranging from 0 to 100 and sum to 100 for the (group) sample. 
e.g. with low levels of visible fat. Illichimann and Abdulai [83] discovered that health-conscious buyers trust organic labels and the benefits of organic attributes such as promotion of sustainable development, improvement of human health and animal husbandry. In addition, the members in this class are willing to pay a price premium in order to avoid conventional food. The second biggest class is the hedonic group (31.90\%). The tactile sense and visual appearance of the sweet peppers are appreciated as important attributes for the hedonic group. In addition, this group is rather price sensitive. This is in agreement with [82], who determined a consumer group that is visual oriented and prefers bright red colour for beef and low meat prices. The third class, the CoO-driven shoppers (17.90\%) perceived the $\mathrm{CoO}$ information to be the most relevant criterion when buying sweet pepper, followed with some distance by price and the labelling of production methods. While many of the previous studies have determined that the $\mathrm{CoO}$ information has played an important role in consumers' food consumption and preference [8] [81] [84], in our study findings also reveal the presence of a market segment interested in the CoO labelling of the foods.

Finally, the Kruskal-Wallis non-parametric test [71] was employed to further explore whether the three consumer groups significantly differ with respect to demographic variables among the segments. Table 7 reveals that the three clusters are significantly different regarding age, living area and education. Hedonic buyers consist mainly of respondents who are older (over 50 years old), dwell in urban areas and possess a lower level of education (up to the degree of senior high school). As pointed out by [85] younger consumers attach less importance to sensory criteria whereas older respondents declared sensory factors very important for meat quality. Health conscious purchasers comprise respondents who are younger (up to 29 years old) and have a university degree. This result is in line with the finding reported by [28] that the younger the consumers; the greater importance they give to organic production specification, and [86] that higher educated consumers are more likely to perceive environmental effect of organic agriculture. The CoO-driven shoppers contain largely of middle age respondents (aged between 30 - 49 years old) who live in the mid-sized cities and hold a university degree. This support the finding of [87] that the middle age and the higher educated consumers pay a higher level of attention to the label of CoO.

\section{Conclusions}

Many scholars and marketers have been trying to find which food attributes have the highest impact on consumers' food choice and what are those consumers' profiles. As food is based on several (combined) attributes that might influence consumers in the process of their purchase decision making, this task is rather difficult to achieve. Particularly, consumers' food purchase decision is not only constructed exclusively by visible cues, but it is also determined by a combination of different outward factors. This study presents an empirical analysis of how food attributes influence decisions of consumers' food purchase decision 
Table 7. Demographic profiles among three latent segments.

\begin{tabular}{|c|c|c|c|c|}
\hline \multirow[t]{2}{*}{ Number of total participants } & \multicolumn{4}{|c|}{795} \\
\hline & $\begin{array}{c}\text { Hedonic } \\
\text { buyers }\end{array}$ & $\begin{array}{l}\text { Health-conscious } \\
\text { purchasers }\end{array}$ & $\begin{array}{l}\text { COO driven } \\
\text { shoppers }\end{array}$ & $\begin{array}{l}\text { Asymp. } \\
\text { Sig. }\end{array}$ \\
\hline \multirow[t]{2}{*}{ Sample size } & $31.90 \%$ & $50.20 \%$ & $17.90 \%$ & \\
\hline & (\%) & (\%) & (\%) & \\
\hline \multicolumn{5}{|l|}{ Shopping responsibility } \\
\hline Full & 42.5 & 43.9 & 46.6 & \\
\hline Partly & 57.5 & 56.1 & 53.4 & \\
\hline \multicolumn{5}{|l|}{ Gender } \\
\hline Male & 32.8 & 30.0 & 26.7 & \\
\hline Female & 67.2 & 70.0 & 73.3 & \\
\hline Age & & & & $* *$ \\
\hline Up to 29 & 14.2 & 25.3 & 13.7 & \\
\hline $30-49$ & 59.7 & 58.9 & 67.4 & \\
\hline 50 and over & 24.7 & 15.8 & 18.1 & \\
\hline n.a. & 1.5 & 0 & 0.7 & \\
\hline \multicolumn{5}{|l|}{ Living location } \\
\hline North & 36.6 & 25.7 & 20.3 & \\
\hline Middle & 24.6 & 38.3 & 45.3 & \\
\hline South & 38.1 & 34.8 & 32.1 & \\
\hline Other (e.g. East or Islands) & 0.7 & 1.2 & 2.3 & \\
\hline Living Area & & & & $*$ \\
\hline Bid city & 54.5 & 45.5 & 45.1 & \\
\hline Middle size city & 29.1 & 27.3 & 29.2 & \\
\hline Rural area or countryside & 16.4 & 27.2 & 25.7 & \\
\hline \multicolumn{5}{|l|}{ Marital status } \\
\hline Single & 29.1 & 35.2 & 31.4 & \\
\hline Married & 62.7 & 55.7 & 64.7 & \\
\hline Other (e.g. divorced/ widowed) & 6.7 & 6.3 & 2.9 & \\
\hline n.a. & 1.5 & 2.8 & 1.0 & \\
\hline Education & & & & $* * *$ \\
\hline Senior high school (12 years) & 30.6 & 15.8 & 23.0 & \\
\hline College & 22.4 & 22.1 & 23.0 & \\
\hline University and over & 43.3 & 54.5 & 50.7 & \\
\hline n.a. & 3.7 & 7.5 & 3.3 & \\
\hline \multicolumn{5}{|l|}{ Monthly net income in a household } \\
\hline Up to NT 60,000 & 22.9 & 37.1 & 37.8 & \\
\hline NT 60,001 and over & 58.1 & 39.0 & 44.1 & \\
\hline n.a. & 9.0 & 23.9 & 18.1 & \\
\hline
\end{tabular}

$* * *, * *,{ }^{*}$ Demographics are significant at $0.1 \%, 1 \%, 5 \%$, level with asymptotic method of non-parametric Kruskal-Wallis test among three latent segments. 
in Taiwan. The BWS methodology of choice experiment is used to overcome the limitations of the traditional rating scales and to further investigate the effect of varying food related attributes as well as environmental factors in order to shed light on the determinants of consumers' purchase decision for sweet peppers. The participants are given BWS choice tasks and forced to make a trade off among items via indicating the most important and the least important item from each BWS choice task. Overall, the CRT information which has the greatest impact on respondents' choice, followed by the labelling of $\mathrm{CoO}$, production methods and the tactile sense. In addition, the LCA results show that consumers can be segmented into three sub-groups based on their preference structure: The health-conscious consumers comprise the largest group (50.20\%). Especially for younger and highly educated people, organic production is becoming an increasing factor in the food purchasing process. For such a case, an informative campaign or advertisement addressing the healthy impact of food could be a practical marketing strategy focusing on younger consumers. However, there are also groups of consumers placing a strong emphasis on sensory-oriented cues of the product (hedonic segment, 31.90\%) and the $\mathrm{CoO}$ labelling (CoO driven shoppers, $17.90 \%)$. In a holistic marketing standpoint, a marketer has to discover a way to understand the needs and the demands of consumers, and further choose which markets to target and to keep consumers through delivering and communicating superior consumer value. The preference heterogeneity detected in the study can be therefore used by food marketers and traders to customize marketing and trading in order to offer differentiated products in line with consumer preferences, as well as developing a useful promotion strategy.

Some potential limitations of this study must be acknowledged when interpreting and concluding the generalizability of the results. First, the BWS experiment, though carefully designed to enable realistic responses, was undertaken in an unnatural and imaginative situation. This might reduce the external validity of the modelled estimates. Second, this study focused on one (agri-) product category, fresh sweet pepper, with participants choosing from within the portfolio of sweet pepper-related attributes. Therefore, the results are limited to the conditions tested and cannot be generalized to other product categories. In addition, it might be useful to consider food values related to food consumption patterns reported by [88], such as the aspects of tradition, fairness, and environmental impact, in the future research. Third, the author suggested that further research could connect a choice-based experiment with behaviour approaches, for example using structural behaviour modelling to investigate the cognitive and affective constructs influencing consumers' purchase decision. Fourth, it must be noted that there are nine attributes used in this study; however, including one additional attribute or removing a chosen one in the BWS design, the analytical results can be significantly changed. As in the BWS setting each attribute is evaluated respectively in relation to the other remaining attributes. Finally, this paper provides a better understanding and insights regarding to the importance of agri-food purchase related cues in Taiwanese consumers' food 
choice using the BWS method. From the theoretical and methodological perspective, the author recommends taking the advantage of this method (given the fact it reduces participants' cognitive burden and force participants to trade off) to conduct further in-depth explorations.

\section{Conflicts of Interest}

The author declares no conflicts of interest regarding the publication of this paper.

\section{References}

[1] Caswell, J.A. and Padberg, D.I. (1992) Toward a More Comprehensive Theory of Food Labels. American Journal of Agricultural Economics, 74, 460-468.

https://doi.org/10.2307/1242500

[2] Caswell, J.A. (1998) How Labeling of Safety and Process Attributes Affects Markets for Food. Agricultural and Resource Economics Review, 27, 151-158. https://doi.org/10.1017/S106828050000647X

[3] Lim, K.H., Hu, W., Maynard, L.J. and Goddard, E. (2013) US Consumers' Preference and Willingness to Pay for Country-of-Origin-Labeled Beef Steak and Food Safety Enhancements. Canadian Journal of Agricultural Economics/ Revue Canadienne d' Agroeconomie, 61, 93-118. https://doi.org/10.1111/j.1744-7976.2012.01260.x

[4] Denver, S. and Jensen, J.D. (2014) Consumer Preferences for Organically and Locally Produced Apples. Food Quality and Preference, 31, 129-134. https://doi.org/10.1016/j.foodqual.2013.08.014

[5] De-Magistris, T. and Gracia, A. (2014) Do Consumers Care about Organic and Distance Labels? An Empirical Analysis in Spain. International Journal of Consumer Studies, 38, 660-669. https://doi.org/10.1111/ijcs.12138

[6] Hu, W., Batte, M.T., Woods, T. and Ernst, S. (2012) Consumer Preferences for Local Production and Other Value-Added Label Claims for a Processed Food Product. European Review of Agricultural Economics, 39, 489-510. https://doi.org/10.1093/erae/jbr039

[7] Nguyen, T.T., Haider, W., Solgaard, H.S., Ravn-Jonsen, L. and Roth, E. (2015) Consumer Willingness to Pay for Quality Attributes of Fresh Seafood: A Labelled Latent Class Model. Food Quality and Preference, 41, 225-236. https://doi.org/10.1016/j.foodqual.2014.12.007

[8] Lagerkvist, C.J., Berthelsen, T., Sundström, K. and Johansson, H. (2014) Country of Origin or EU/Non-EU Labelling of Beef? Comparing Structural Reliability and Validity of Discrete Choice Experiments for Measurement of Consumer Preferences for Origin and Extrinsic Quality Cues. Food Quality and Preference, 34, 50-61. https://doi.org/10.1016/j.foodqual.2013.12.009

[9] Ortega, D.L., Hong, S.J., Wang, H.H. and Wu, L. (2016) Emerging Markets for Imported Beef in China: Results from a Consumer Choice Experiment in Beijing. Meat Science, 121, 317-323. https://doi.org/10.1016/j.meatsci.2016.06.032

[10] Adams, D.C. and Salois, M.J. (2010) Local versus Organic: A Turn in Consumer Preferences and Willingness-to-Pay. Renewable Agriculture and Food Systems, 25, 331-341. https://doi.org/10.1017/S1742170510000219

[11] Xie, J., Gao, Z., Swisher, M. and Zhao, X. (2016) Consumers' Preferences for Fresh Broccolis: Interactive Effects between Country of Origin and Organic Labels. Agri- 
cultural Economics, 47, 181-191. https://doi.org/10.1111/agec.12193

[12] Nganje, W.E., Shaw Hughner, R. and Lee, N.E. (2011) State-Branded Programs and Consumer Preference for Locally Grown Produce. Agricultural and Resource Economics Review, 40, 20-32. https://doi.org/10.1017/S1068280500004494

[13] Jaafar, S.N., Lalp, P.E. and Naba, M.M. (2012) Consumers' Perceptions, Attitudes and Purchase Intention towards Private Label Food Products in Malaysia. Asian Journal of Business and Management Sciences, 2, 73-90.

[14] Lawless, H.T. and Heymann, H. (2010) Principles of Good Practice. In: Sensory Evaluation of Food. Food Science Text Series, Springer, New York, 57-77. https://doi.org/10.1007/978-1-4419-6488-5 3

[15] Roost, B.G.B.H.M. (2013) Touching a Product: Essential or Expendable? Replicating Haptic Product Exploration via Other Senses. Master's Thesis, University of Twente, Enschede.

[16] Tzia, C., Giannou, V., Lignou, S. and Lebesi, D. (2015) Sensory Evaluation of Foods. In: Varzakas, T. and Tzia, C., Eds., Handbook of Food Processing. Food Safety, Quality, and Manufacturing Processes, CRC Press, Boca Raton, FL, 41-71.

[17] Bond, J.K., Thilmany, D. and Bond, C.A. (2006) Direct Marketing of Fresh Produce: Understanding Consumer Purchasing Decisions. Choices, 21, 229-236.

[18] Thilmany, D., Bond, C.A. and Bond, J.K. (2008) Going Local: Exploring Consumer Behavior and Motivations for Direct Food Purchases. American Journal of Agricultural Economics, 90, 1303-1309. https://doi.org/10.1111/j.1467-8276.2008.01221.x

[19] Ajzen, I. (2011) Theory of Planned Behavior. In: Van Lange, P.A.M., Kruglanski, A.W. and Higgins, E.T., Eds., Handbook of Theories of Social Psychology, Sage Publishing, Thousand Oaks, CA, 438-459. https://doi.org/10.4135/9781446249215.n22

[20] Kuznesof, S. and Ritson, C. (1996) Consumer Acceptability of Genetically Modified Foods with Special Reference to Farmed Salmon. British Food Journal, 98, 39-47. https://doi.org/10.1108/00070709610119874

[21] Onozaka, Y. and McFadden, D.T. (2011) Does Local Labeling Complement or Compete with Other Sustainable Labels? A Conjoint Analysis of Direct and Joint Values for Fresh Produce Claim. American Journal of Agricultural Economics, 93, 693-706. https://doi.org/10.1093/ajae/aar005

[22] Loureiro, M.L. and Umberger, W.J. (2007) A Choice Experiment Model for Beef: What US Consumer Responses Tell Us about Relative Preferences for Food Safety, Country-of-Origin Labeling and Traceability. Food Policy, 32, 496-514.

https://doi.org/10.1016/j.foodpol.2006.11.006

[23] Ding, M., Grewal, R. and Liechty, J. (2005) Incentive-Aligned Conjoint Analysis. Journal of Marketing Research, 42, 67-82. https://doi.org/10.1509/jmkr.42.1.67.56890

[24] Gracia, A. (2014) Consumers' Preferences for a Local Food Product: A Real Choice Experiment. Empirical Economics, 47, 111-128. https://doi.org/10.1007/s00181-013-0738-x

[25] Moser, R., Raffaelli, R. and Notaro, S. (2013) Testing Hypothetical Bias with a Real Choice Experiment Using Respondents' Own Money. European Review of Agricultural Economics, 41, 25-46. https://doi.org/10.1093/erae/jbt016

[26] Hein, K.A., Jaeger, S.R., Carr, B.T. and Delahunty, C.M. (2008) Comparison of Five Common Acceptance and Preference Methods. Food Quality and Preference, 19, 651-661. https://doi.org/10.1016/j.foodqual.2008.06.001 
[27] Casini, L. and Corsi, A.M. (2009) Consumer Preferences of Wine in Italy Applying Best-Worst Scaling. International Journal of Wine Business Research, 21, 64-78. https://doi.org/10.1108/17511060910948044

[28] Bernabéu, R., Díaz, M., Olivas, R. and Olmeda, M. (2012) Consumer Preferences for Wine Applying Best-Worst Scaling: A Spanish Case Study. British Food Journal, 114, 1228-1250. https://doi.org/10.1108/00070701211258790

[29] Finn, A. and Louviere, J.J. (1992) Determining the Appropriate Response to Evidence of Public Concern: The Case of Food Safety. Journal of Public Policy \& Marketing, 11, 12-25. https://doi.org/10.1177/074391569201100202

[30] Cohen, S.H. and Markowitz, P. (2002) Renewing Market Segmentation: Some New Tools to Correct old Problems. ESOMAR 2002 Congress Proceedings, 595-612.

[31] Lee, J.A., Soutar, G.N. and Louviere, J. (2007) Measuring Values Using Best-Worst Scaling: The LOV Example. Psychology \& Marketing, 24, 1043-1058. https://doi.org/10.1002/mar.20197

[32] Dekhili, S., Sirieix, L. and Cohen, E. (2011) How Consumers Choose Olive Oil: The Importance of Origin Cues. Food Quality and Preference, 22, 757-762. https://doi.org/10.1016/j.foodqual.2011.06.005

[33] Chrysochou, P., Krystallis, A., Mocanu, A. and Leigh Lewis, R. (2012) Generation Y Preferences for Wine: An Exploratory Study of the US Market Applying the Best-Worst Scaling. British Food Journal, 114, 516-528. https://doi.org/10.1108/00070701211219531

[34] Morgan, C.J., Widmar, N.O., Yeager, E.A., Downey, W.S. and Croney, C.C. (2016) Perceptions of Social Responsibility of Prominent Fast Food Restaurants. Modern Economy, 7, 704-714. https://doi.org/10.4236/me.2016.76074

[35] Cummins, A.M., Widmar, N.J.O., Croney, C.C. and Fulton, J.R. (2016) Understanding Consumer Pork Attribute Preferences. Theoretical Economics Letters, 6, 166-177. https://doi.org/10.4236/tel.2016.62019

[36] McFadden, D. and Zarembka, P. (1974) Conditional Logit Analysis of Qualitative Choice Behavior. In: Zarembka, P., Ed., Frontiers in Econometrics, Academic Press, 105-142.

[37] Thurstone, L.L. (1927) A Law of Comparative Judgment. Psychological Review, 34, 273-286. https://doi.org/10.1037/h0070288

[38] Louviere, J.J., Flynn, T.N. and Marley, A.A.J. (2015) Best-Worst Scaling: Theory, Methods and Applications. Cambridge University Press, Cambridge.

https://doi.org/10.1017/CBO9781107337855

[39] Ahmed, Z.U., Johnson, J.P., Yang, X., Fatt, C.K., Teng, H.S. and Boon, L.C. (2004) Does Country of Origin Matter for Low-Involvement Products? International Marketing Review, 21, 102-120. https://doi.org/10.1108/02651330410522925

[40] Josiassen, A., Lukas, B.A. and Whitwell, G.J. (2008) Country-of-Origin Contingencies: Competing Perspectives on Product Familiarity and Product Involvement. International Marketing Review, 25, 423-440. https://doi.org/10.1108/02651330810887477

[41] Hsu, C.L. and Chen, M.C. (2014) Explaining Consumer Attitudes and Purchase Intentions toward Organic Food: Contributions from Regulatory Fit and Consumer Characteristics. Food Quality and Preference, 35, 6-13. https://doi.org/10.1016/j.foodqual.2014.01.005

[42] Teng, C.C. and Lu, C.H. (2016) Organic Food Consumption in Taiwan: Motives, Involvement, and Purchase Intention under the Moderating Role of Uncertainty. Appetite, 105, 95-105. https://doi.org/10.1016/j.appet.2016.05.006 
[43] Bruhn, C.M., Diaz-Knauf, K., Feldman, N., Harwood, J.A.N., Ho, G., Ivans, E., Kubin, L., Lamp, C., Marshall, M., Osaki, S., Stanford, G., Steinbring, Y., Valdez, I, Williamson, E. and Wunderlich, E. (1991) Consumer Food Safety Concerns and Interest in Pesticide-Related Information. Journal of Food Safety, 12, 253-262. https://doi.org/10.1111/j.1745-4565.1991.tb00082.x

[44] Hsu, L.-L., Cheng, S.-H., Cheng, S.-S., Shyu, J.-F., Su, S.-C., Chou, S.-S. and Chen, T.-H. (2006) Monitoring of Pesticide Residues in Packed Vegetables and Fruit from Packing Field. Annual Scientific Report of National Laboratories of Foods and Drugs, Department of Health, 290-300.

[45] Liu, C.-J. (2013) The Impact of Market Orientation and Participation Behavior on Word-of-Mouth: Case of Taiwanese Chain Supermarket. Master Thesis, Yu Da University, Taiwan. http://ir.ydu.edu.tw/bitstream/310997200/10097/2/99100003.pdf

[46] Greenpeace (2016) Evaluation Report: Pesticide Evaluation for Supermarkets and Hypermarkets.

[47] Buder, F., Feldmann, C. and Hamm, U. (2014) Why Regular Buyers of Organic Food Still Buy Many Conventional Products: Product-Specific Purchase Barriers for Organic Food Consumers. British Food Journal, 116, 390-404.

https://doi.org/10.1108/BFJ-04-2012-0087

[48] Geslani, C., Loke, M.K., Barnes-Mauthe, M. and Leung, P. (2015) Seafood Purchasing Preferences of Hawaii Chefs: Comparing Actual Purchase to Stated Preferences From Conjoint Choice Experiment. Journal of International Food \& Agribusiness Marketing, 27, 50-63. https://doi.org/10.1080/08974438.2013.833569

[49] Sinha, P.K. and Banerjee, A. (2004) Store Choice Behaviour in an Evolving Market. International Journal of Retail \& Distribution Management, 32, 482-494. https://doi.org/10.1108/09590550410558626

[50] Sinha, P.K., Banerjee, A. and Uniyal, D.P. (2002) Deciding Where to Buy: Store Choice Behaviour of Indian Shoppers. Vikalpa: The Journal for Decision Makers, 27, 13-28. https://doi.org/10.1177/0256090920020203

[51] Balaji, M.S., Raghavan, S. and Jha, S. (2011) Role of Tactile and Visual Inputs in Product Evaluation: A Multisensory Perspective. Asia Pacific Journal of Marketing and Logistics, 23, 513-530. https://doi.org/10.1108/13555851111165066

[52] Swahn, J., Mossberg, L., Öström, Å. and Gustafsson, I.B. (2012) Sensory Description Labels for Food Affect Consumer Product Choice. European Journal of Marketing, 46, 1628-1646. https://doi.org/10.1108/03090561211260013

[53] Oltman, A.E., Jervis, S.M. and Drake, M.A. (2014) Consumer Attitudes and Preferences for Fresh Market Tomatoes. Journal of Food Science, 79, S2091-S2097. https://doi.org/10.1111/1750-3841.12638

[54] Scott, M.L., Nowlis, S.M., Mandel, N. and Morales, A.C. (2008) The Effects of Reduced Food Size and Package Size on the Consumption Behavior of Restrained and Unrestrained Eaters. Journal of Consumer Research, 35, 391-405. https://doi.org/10.1086/591103

[55] Aerni, P., Scholderer, J. and Ermen, D. (2011) How Would Swiss Consumers Decide If They Had Freedom of Choice? Evidence from a Field Study with Organic, Conventional and GM Corn Bread. Food Policy, 36, 830-838. https://doi.org/10.1016/j.foodpol.2011.08.002

[56] Wansink, B. (1996) Can Package Size Accelerate Usage Volume? The Journal of Marketing, 60, 1-14. https://doi.org/10.1177/002224299606000301

[57] Andorfer, V.A. and Liebe, U. (2013) Consumer Behavior in Moral Markets. On the 
Relevance of Identity, Justice Beliefs, Social Norms, Status, and Trust in Ethical Consumption. European Sociological Review, 29, 1251-1265.

https://doi.org/10.1093/esr/jct014

[58] Pliner, P. and Mann, N. (2004) Influence of Social Norms and Palatability on Amount Consumed and Food Choice. Appetite, 42, 227-237.

https://doi.org/10.1016/j.appet.2003.12.001

[59] Sawtooth Software (2007) The MaxDiff v6.0 Technical Paper. Sawtooth Software Inc., USA.

[60] De-Magistris, T. and Royo, A.G. (2014) Wine Consumers Preferences in Spain: An Analysis Using the Best-Worst Scaling Approach. Spanish Journal of Agricultural Research, 12, 529-541. https://doi.org/10.5424/sjar/2014123-4499

[61] Lagerkvist, C.J., Okello, J. and Karanja, N. (2012) Anchored vs. Relative Best-Worst Scaling and Latent Class vs. Hierarchical Bayesian Analysis of Best-Worst Choice Data: Investigating the Importance of Food Quality Attributes in a Developing Country. Food Quality and Preference, 25, 29-40. https://doi.org/10.1016/j.foodqual.2012.01.002

[62] Cohen, E. (2009) Applying Best-Worst Scaling to Wine Marketing. International Journal of Wine Business Research, 21, 8-23. https://doi.org/10.1108/17511060910948008

[63] Goodman, S. (2009) An International Comparison of Retail Consumer Wine Choice. International Journal of Wine Business Research, 21, 41-49. https://doi.org/10.1108/17511060910948026

[64] Erdem, S. and Rigby, D. (2013) Investigating Heterogeneity in the Characterization of Risks Using Best Worst Scaling. Risk Analysis, 33, 1728-1748. https://doi.org/10.1111/risa.12012

[65] Train, K. (2009) Discrete Choice Methods with Simulation. 2nd Edition, Cambridge University Press, Cambridge.

[66] Haughton, D., Legrand, P. and Woolford, S. (2009) Review of Three Latent Class Cluster Analysis Packages: Latent Gold, poLCA, and MCLUST. The American Statistician, 63, 81-91. https://doi.org/10.1198/tast.2009.0016

[67] Hauser, J.R. (1978) Testing the Accuracy, Usefulness, and Significance of Probabilistic Choice Models: An Information-Theoretic Approach. Operations Research, 26, 406-421. https://doi.org/10.1287/opre.26.3.406

[68] Ogawa, K. (1987) An Approach to Simultaneous Estimation and Segmentation in Conjoint Analysis. Marketing Science, 6, 66-81. https://doi.org/10.1287/mksc.6.1.66

[69] Akaike, H. (1974) A New Look at the Statistical Model Identification. IEEE Transactions on Automatic Control, 19, 716-723. https://doi.org/10.1109/TAC.1974.1100705

[70] Schwarz, G. (1978) Estimating the Dimension of a Model. Annals of Statistics, 6, 461-464. https://doi.org/10.1214/aos/1176344136

[71] Kruskal, W.H. and Wallis, W.A. (1952) Use of Ranks in One-Criterion Variance Analysis. Journal of the American Statistical Association, 47, 583-621. https://doi.org/10.1080/01621459.1952.10483441

[72] Schnettler, B., Vidal, R., Silva, R., Vallejos, L. and Sepúlveda, N. (2009) Consumer Willingness to Pay for Beef Meat in a Developing Country: The Effect of Information Regarding Country of Origin, Price and Animal Handling Prior to Slaughter. Food Quality and Preference, 20, 156-165. https://doi.org/10.1016/j.foodqual.2008.07.006 
[73] Baker, M.J. and Ballington, L. (2002) Country of Origin as a Source of Competitive Advantage. Journal of Strategic Marketing, 10, 157-168. https://doi.org/10.1080/09652540210125297

[74] Hirche, M. and Bruwer, J. (2014) Buying a Product for an Anticipated Consumption Situation: Observation of High- and Low-Involved Wine Buyers in a Retail Store. International Journal of Wine Business Research, 26, 295-318. https://doi.org/10.1108/IJWBR-01-2014-0007

[75] Betts, E., Christensen, L., Klein, C., Mura, N. and Sturgess, B. (2010) Chinese Consumer Behaviour towards Sustainable Kiwifruit Production. Report for Zespri International Limited.

[76] Yeh, C.H. and Hartmann, M. (2016) Consumers' Preference for Sweet Peppers with different Process Attributes: A Discrete Choice Experiment in Taiwan. International Journal on Food System Dynamics, 7, 293-310.

[77] Coltman, T.R., Devinney, T.M. and Keating, B.W. (2011) Best-Worst Scaling Approach to Predict Customer Choice for 3PL Services. Journal of Business Logistics, 32, 139-152. https://doi.org/10.1111/j.2158-1592.2011.01012.x

[78] Lin, T.H. and Dayton, C.M. (1997) Model Selection Information Criteria for Non-Nested Latent Class Models. Journal of Educational and Behavioral Statistics, 22, 249-264. https://doi.org/10.3102/10769986022003249

[79] McCutcheon, A.L. (2002) Basic Concepts and Procedures in Single- and Multiple-Group Latent Class Analysis. In: McCutcheon, A.L., Ed., Applied Latent Class Analysis, Cambridge University Press, Cambridge, 56-88.

https://doi.org/10.1017/CBO9780511499531.003

[80] Nylund, K.L., Asparouhov, T. and Muthén, B.O. (2007) Deciding on the Number of Classes in Latent Class Analysis and Growth Mixture Modeling: A Monte Carlo Simulation Study. Structural Equation Modeling, 14, 535-569. https://doi.org/10.1080/10705510701575396

[81] Mauracher, C., Tempesta, T. and Vecchiato, D. (2013) Consumer Preferences Regarding the Introduction of New Organic Products. The Case of the Mediterranean Sea Bass (Dicentrarchus labrax) in Italy. Appetite, 63, 84-91. https://doi.org/10.1016/j.appet.2012.12.009

[82] Realini, C.E., Kallas, Z., Pérez-Juan, M., Gómez, I., Olleta, J.L., Beriain, M.J., Alberti, P. and Sañudo, C. (2014) Relative Importance of Cues Underlying Spanish Consumers' Beef Choice and Segmentation, and Consumer Liking of Beef Enriched with n-3 and CLA Fatty Acids. Food Quality and Preference, 33, 74-85. https://doi.org/10.1016/j.foodqual.2013.11.007

[83] Illichmann, R. and Abdulai, A. (2013) Analysis of Consumer Preferences and Willingness-to-Pay for Organic Food Products in Germany. 2013 Annual Meeting, Washington DC, 4-6 August 2013, 25-27.

[84] Cosmina, M., Gallenti, G., Marangon, F. and Troiano, S. (2016) Attitudes towards Honey among Italian Consumers: A Choice Experiment Approach. Appetite, 99, 52-58. https://doi.org/10.1016/j.appet.2015.12.018

[85] Issanchou, S. (1996) Consumer Expectations and Perceptions of Meat and Meat Product Quality. Meat Science, 43, 5-19. https://doi.org/10.1016/0309-1740(96)00051-4

[86] Canavari, M., Bazzani, G.M., Spadoni, R. and Regazzi, D. (2002) Food Safety and Organic Fruit Demand in Italy: A Survey. British Food Journal, 104, 220-232. https://doi.org/10.1108/00070700210425688

[87] Verbeke, W. and Ward, R.W. (2006) Consumer Interest in Information Cues De- 
noting Quality, Traceability and Origin: An Application of Ordered Probit Models to Beef Labels. Food Quality and Preference, 17, 453-467.

https://doi.org/10.1016/j.foodqual.2005.05.010

[88] Lusk, J.L. and Briggeman, B.C. (2009) Food Values. American Journal of Agricultural Economics, 91, 184-196. https://doi.org/10.1111/j.1467-8276.2008.01175.x 